\title{
TIPE - TIPE BELAJAR DALAM PROSES \\ PEMBELAJARAN
}

\author{
Ishak Wanto Talibo \\ STAIN Manado \\ ishakwantotalibo@yahoo.co.id
}

\begin{abstract}
Abstrak
Penguasaan terhadap tipe-tipe belajar pembelajaran yang secara langsung dapat meningkatkan kompetensi pedagogis adalah sebagai usaha nyata (quality assurance) profesionalisme pembelajaran. Penguasaan terhadap tipe-tipe pembelajaran juga dapat diartikan sebagai bukti keseriusan pendidik untuk meningkatkan secara berkelanjutan kualitas proses pembelajaran peserta didik sebagai stakeholders, bahkan merupakan salah satu bukti komitmen pendidik dalam meningkatkan profesionalismenya dengan paradigma baru pembelajaran. Kualitas pembelajaran seorang pendidik sangat strategis karena ia berfungsi sebagai ujung tombak terjadinya perubahan (the agent of change) dari belum bisa menjadi bisa, dari belum menguasai menjadi menguasai dan belum mengerti menjadi mengerti. Oleh karena itu, keberhasilan perubahan suatu kualitas pengajaran suatu lembaga pendidikan apapun tergantung kepada keberhasilan kualitas pendidik dalam menerapkan tipe-tipe belajar di dalam proses pembelajaran, kualitas tidak menjadi sekonyong-konyong tapi berakar dari sebuah perencanaan, kerja keras dan komitmen, gagal menerapkan tipe-tipe belajar dalam proses pembelajaran berarti gagal pula melaksanakan dan menyelenggarakan proses belajar mengajar dengan baik, yang menyebabkan hasilnya tidak sesuai dengan tujuan yang diharapkan.
\end{abstract}

Kata Kunci : Tipe-tipe Belajar, Proses, Pembelajaran 


\section{A. Pendahuluan}

Keberhasilan implementasi kurikulum sangat dipengaruhi oleh kemampuan guru yang akan menerapkan dan mengaktualisasikan kurikulum tersebut. Kemampuan guru tersebut terutama berkaitan dengan pengetahuan dan kemampuan, serta tugas yang dibebankan kepadanya. Tidak jarang kegagalan implementasi kurikulum disebabkan oleh kurangnya pengetahuan, keterampilan, dan kemampuan guru dalam memahami tugas yang harus dilaksanakannya. Kondisi ini menunjukkan bahwa berfungsinya kurikulum terletak pada bagaimana pelaksanaannya di sekolah, khususnya di kelas di dalam kegiatan pembelajaran yang merupakan kunci keberhasilan tersebut.

Kegiatan belajar yang berlangsung di sekolah bersifat formal, disengaja, direncanakan, dengan bimbingan guru, dan bantuan pendidik lainnya. Apa yang hendak dicapai dan dikuasai oleh siswa dituangkan dalam tujuan belajar, dipersiapkan bahan apa yang harus di pelajari, di persiapkan juga metode pembelajaran yang sesuai dengan bagaimana cara siswa mempelajarinya, dan melakukan evaluasi untuk mengetahui kemajuan belajar siswa. Persiapan ini telah direncanakan dengan seksama oleh guru mengacu pada kurikulum mata pelajaran. Penjelasan ini memberi gambaran bahwa kegiatan belajar yang di laksanakan secara sengaja di persiapkan dalam bentuk perencanaan pengajaran, persiapan pengajaran sebagai kegiatan integral dan proses pembelajaran di sekolah.

Setiap kegiatan belajar mengajar selalu melakukan dua perilaku aktif, yaitu guru dan siswa, guru sebagai pengajar merupakan pencipta kondisi belajar siswa yang didesain secara sengaja, antimatis dan berkesinambungan, sedangkan anak sebagai subyek pembelajaran merupakan pihak yang menikmati kondisi belajar yang diciptakan guru.

Perpaduan dari kedua unsur manusiawi ini melahirkan interaksi edukatif dengan memanfaatkan bahan ajaran sebagai mediumnya. Pada kegiatan belajar mengajar, keduanya (guru-murid) saling mempengaruhi dan memberi masukan. Karena itulah kegiatan belajar mengajar harus merupakan aktivitas yang hidup, sarat nilai dan senantiasa memiliki tujuan. 
Rumusan belajar mengajar tradisional, selalu menempatkan anak didik sebagai obyek pembelajaran dan guru sebagai subyeknya. ${ }^{1}$ Rumusan ini membawa konsekuensi terhadap kurang bermaknanya kedudukan anak dalam keseluruhan proses belajar mengajar.

Pendekatan baru melihat bahwa kegiatan belajar mengajar merupakan milik guru dan murid, dalam kedudukan guru yang setara, namun dari segi fungsi berbeda. Anak merupakan subjek pembelajaran dan menjadi inti dari setiap kegiatan pendidikan. Proses pengajaran yang mengesampingkan martabat anak bukanlah proses pendidikan yang benar. Bahkan merupakan kekeliruan yang tidak bisa di abaikan begitu saja. Karena itulah, inti proses pengajaran tidak lain adalah kegiatan belajar anak didik dalam mencapai suatu tujuan pengajaran. Tujuan pengajaran tentu saja akan dapat tercapai jika anak didik berusaha secara aktif untuk mencapainya. Keaktifan anak didik di sini tidak hanya dituntut dari segi fisik, tetapi juga dari segi kejiwaan, apabila hanya fisik anak yang aktif, tetapi pikiran dan mentalnya kurang aktif, maka kemungkinan besar tujuan pembelajaran tidak tercapai. Ini sama halnya dengan anak didik tidak belajar, karena anak didik tidak merasakan perubahan di dalam dirinya.

Kegiatan mengajar bagi seorang guru membutuhkan hadirnya sejumlah anak didik. Hal ini berbeda dengan belajar yang tidak selamanya memerlukan kehadiran seorang guru. Cukup banyak aktivitas yang dilakukan oleh seseorang di luar dari keterlibatan guru. Belajar di rumah cenderung menyediri dan tidak terlalu banyak mengharapkan bantuan orang lain. Apalagi aktivitas belajar itu berkenaan dengan kegiatan membaca buku tertentu.

Mengajar merupakan kegiatan dimana keterlibatan individu anak didik mutlak adanya. Apabila tidak ada anak didik atau objek didik yang diajar. Hal ini perlu sekali disadari guru agar tidak terjadi kesalahan tafsir terhadap kegiatan pengajaran. Karena itu, belajar dan mengajar merupakan istilah yang sudah baku dan menyatu dalam konsep pengajaran atau pendidikan.

${ }^{1}$ Abdul Majid, Perencanaan Pembelajaran (mengembangkan standar Kompetensi guru), Cet. III: Bandung : PT Remaja Rosda Karya, 2007, h. 15 
Biasanya permasalahan yang guru hadapi ketika berhadapan dengan sejumlah anak didik adalah masalah pengelolaan kelas. Apa, siapa, bagaimana, kapan, dan di mana adalah serentetan pertanyaan yang perlu dijawab dalam hubungannya dengan masalah pengelolaan kelas. Peran guru itu paling tidak berusaha untuk mengatur suasana kelas yang kondusif bagi kegairahan dan kesenangan belajar anak didik. Jadi, masalah pengaturan kelas selalu terkait dengan kegiatan guru. Semua kegiatan yang dilakukan guru tidak lain demi kepentingan anak didik dan demi keberhasilan proses belajar itu sendiri.

Dalam konteks pengajaran, perencanaan dapat diartikan sebagai proses penyusunan materi pelajaran, penggunaan materi pengajaran, penggunaan pendekatan dan metode pengajaran dan penilaian dalam suatu lokasi waktu yang di laksanakan pada suatu waktu. ${ }^{2}$

Demikian perencanaan akan merespon target pemenuhan pembelajaran yang baik diukur dengan prestasi melalui evaluasi, ataupun pelayanan belajar dilihat dari kesiapan dan strategi yang digunakan.

\section{A. Pembahasan}

\section{Tipe Belajar Siswa}

Tipe adalah sesuatu yang dibedakan menurut sifat-sifat seperti arah, minat, perhatian, dan perilaku yang menunjukkan pola-pola kelompok atau jenis-jenis. ${ }^{3}$ Selain itu, tipe juga merupakan suatu khas individu yang dikelompokkan menjadi satu disebabkan mereka memiliki beberapa sifat-sifat kepribadian. ${ }^{4}$

Belajar didefinisikan sebagai usaha memperoleh kepandaian atau ilmu, berupa tingkah laku atau tanggapan yang disebabkan oleh pengalaman. ${ }^{5}$ Belajar juga adalah suatu proses usaha yang dilakukan seseorang untuk memperoleh suatu

\footnotetext{
${ }^{2}$ Abdul Majid, Ibid, h. 17

${ }^{3}$ Sudarsono, Kamus Filsafat dan Psikologi (Jakarta: Rineka Cipta, 1993), h. 91

${ }^{4}$ Kartini Kartono, dkk., Kamus Psikologi (Bandung: Pioneer Jaya, t.th), h. 526

${ }^{5}$ Departemen Pendidikan dan Kebudayaan RI, Kamus Besar Bahasa Indonesia (Jakarta:
} Balai Pustaka, 1988), h. 13 
perubahan tingkah laku yang baru secara keseluruhan, sebagai hasil pengalamannya sendiri dalam interaksi dengan lingkungannya. ${ }^{6}$

Jadi, dapatlah disimpulkan bahwa belajar adalah suatu proses kegiatan yang menimbulkan kelakuan baru atau merubah kelakuan lama, sehingga seseorang lebih mampu memecahkan masalah dan menyesuaikan diri terhadap situasi-situasi yang dihadapi dalam hidupnya. Sedangkan pengertian tipe-tipe belajar yaitu suatu sifat khas yang dimiliki setiap individu yang membedakan dengan individu lainnya dalam proses perubahan tingkah laku sehingga seseorang memiliki kemampuan dalam hidupnya seperti kecakapan intelektual, pengetahuan, sikap, dan keterampilan. Karena setiap individu memiliki tipe atau sifat yang berbedabeda, maka sudah merupakan suatu kepastian bahwa dalam belajar setiap siswa tentu memiliki tipe-tipe yang berbeda pula. Misalnya, setiap individu atau siswa berbeda satu sama lain dalam tingkat kecerdasannya, minat, emosinya, serta pemikiran. Demikian pula dalam belajarnya, ada yang lamban dan ada yang cepat, ada yang mampu belajar sendiri dan ada pula yang berkelompok dan sebagainya, sehingga para ahli berpendapat bahwa setiap jenis belajar merupakan suatu proses belajar tersendiri yang kekhususannya sendiri, yang membedakan dari jenis belajar lain. Namun, semua jenis belajar itu merupakan suatu proses belajar yang menunjukkan gejala-gejala yang terdapat pada semua proses belajar. ${ }^{7}$

\section{Macam-macam Tipe-tipe Belajar}

Setiap siswa memiliki tipe belajar yang berbeda satu sama lainnya. Dengan demikian, sudah merupakan suatu kepastian bahwa tipe-tipe belajar itu bermacam-macam pula, para ahli kebanyakan dari psikolog, membagi tipe-tipe belajar itu kedalam berbagai macam tipe :

- $\quad$ Tipe mendengarkan (auditif)

- Tipe penglihatan (visual)

- Tipe merasakan dan

${ }^{6}$ Slameto, dkk., Belajar dan Faktor-faktor yang Mempengaruhinya (Jakarta: PT. Rineka Cipta, 1995), h. 2

${ }^{7}$ W.S. Winkel, Psikologi Pengajaran, (Jakarta: PT Gramedia, 1989), h. 201 
- $\quad$ Tipe motorik. ${ }^{8}$

Keempat tipe-tipe di atas dapat diketahui bahwa; tipe mendengarkan adalah tipe seorang siswa yang hanya dapat menerima informasi dengan baik apabila ia mendengarkan secara langsung; kemudian tipe penglihatan adalah tipe seorang siswa yang dalam menerima pelajaran dengan baik bila ia melihat secara langsung; tipe merasakan adalah tipe seorang siswa yang dapat menerima informasi dengan baik bila ia melakukan sendiri secara langsung serta tipe motorika adalah tipe seorang yang hanya dapat menerima informasi dengan baik bila ia melakukan sendiri secara langsung.

Selain itu tipe belajar juga dapat dibagi kedalam enam tipe sebagai berikut :

1. Tipe siswa yang visual

2. Tipe yang auditif

3. Tipe siswa yang taktil

4. Tipe siswa yang olpaktoris

5. Tipe siswa yang gustatif, dan

6. Tipe siswa yang campuran (combinative). ${ }^{9}$

\section{Tipe siswa yang visual (lebih mudah belajar melalui penglihatan)}

Tipe belajar siswa yang visual ini adalah mereka yang mengandalkan aktivitas belajarnya kepada materi pelajaran yang dilihatnya. Jadi yang menjadi peranan penting dalam cara belajarnya adalah mata atau penglihatan. Dikatakan demikian karena satu-satunya alat indera yang aktif dan dominan adalah mata. Oleh sebab itu baginya alat peraga adalah sangat penting artinya untuk membantunya dalam penyerapan materi yang disampaikan padanya. Untuk siswa yang bertipe visual ini, cara belajarnya adalah dengan memakai stabilan untuk mencoret-coret kata yang dianggap penting agar ia cepat melihatnya bahwa ini adalah untuk dimengerti. 1992), h. 4

${ }^{8}$ Sriyono, dkk., Tekhnik Belajar Mengajar dalam CBSA, Cet I: (Jakarta: Rineka Cipta,

9 Aminuddin Rasyad, Materi Pokok Media Pengajaran (Cet II: Jakarta: Dirjen Pembinaan Kelembagaan Agama Islam dan Universitas Terbuka, 1993), h. 81 


\section{Tipe siswa yang auditif (lebih mudah belajar melalui pendengaran)}

Siswa yang bertipe auditif ini mengandalkan kesuksesan belajarnya pada alat pendengarannya yaitu telinga. Bagi siswa yang bertipe begini materi pelajaran yang disampaikan kepadanya lebih cepat atau mudah diserapnya apabila materi disajikan secara lisan. Siswa yang bertipe auditif ini, seorang guru harus bersuara besar dan intonasinya tepat sehingga materi yang disajikan dapat berhasil dengan baik. Pendidik dalam menghadapi siswa yang bertipe seperti ini dituntut untuk bertindak bijaksana agar dapat melihat siswa yang pendengarannya agak kurang baik untuk diperhatikan lebih dari teman sekelasnya. Siswa yang bertipe auditif, cara belajarnya adalah apabila ia membaca harus dengan suara yang keras sebab alat indera yang dominant dalam belajarnya adalah telinga.

\section{Tipe siswa yang taktil (lebih mudah belajar melalui perabaan)}

Taktil berarti perabaan atau sentuhan. Siswa yang bertipe taktil adalah siswa yang mengandalkan penyerapan hasil pendidikan/pengajaran melalui alat peraba yaitu tangan dan kulit atau bagian luar tubuh. Siswa yang bertipe ini dengan melalui alat perabanya ia sangat cekatan mempraktekkan hasil pendidikan/pengajaran yang diterimanya seperti ia disuruh mengatur ruang ibadah, menentukan buah-buahan yang sudah busuk, walaupun ia tidak melihatnya, dengan sentuhan tangannya ia segera mengetahui benda yang dirabanya. Cara belajar siswa yang bertipe seperti ini adalah mempraktekkan secara langsung dengan tangannya karena dengan sentuhan tangannya ia dapat mengetahui benda yang dirabanya.

\section{Tipe siswa yang olfaktoris (lebih mudah belajar melalui penciuman)}

Siswa yang bertipe olfaktoris yaitu siswa yang mudah mengikuti pelajaran dengan menggunakan alat inderanya yaitu alat penciuman. Apabila ada materi pelajaran yang menggunakan penciuman seperti bau air atau cairan ia sangat bereaksi disbanding dengan teman-temannya yang tidak bertipe demikian.

Siswa yang bertipe olfaktoris ini akan lebih cepat menyesuaikan diri dengan lingkungan. Siswa yang demikian lebih mudah belajar dengan hal-hal yang berhubungan dengan bau-bauan seperti mengetahui makanan yang sudah basi dan sebagainya. Cara belajar siswa yang bertipe seperti ini adalah mencium segala 
sesuatu yang ada disekitarnya walaupun tidak melihat secara langsung karena alat inderanya yang paling berfungsi adalah hidung.

\section{Tipe siswa yang gustative (lebih mudah belajar melalui kemampuan mencicipi)}

Siswa yang bertipe gustative (kemampuan mencicipi) adalah siswa yang dalam belajarnya mengandalkan kecakapan lidahnya. Siswa yang bertipe ini akan lebih cepat memahami apa yang dipelajarinya melalui indera kecapnya untuk mengetahui berbagai rasa asam, manis, pahit, dan sebagainya. Dalam berwudhu misalnya, siswa yang bertipe ini akan mengetahui kalau air sudah berubah rasa sehingga diragukan kesuciannya. Cara belajar siswa yang bertipe seperti ini adalah dengan mencicipi karena alat inderanya yang paling berfungsi dalam belajarnya adalah lidahnya.

\section{Tipe belajar campuran (combinative)}

Peserta didik yang mempunyai tipe campuran ini mengakuti pelajaran dengan menggunakan inderanya lebih dari satu. Siswa seperti ini dapat mendengarkan radio sambil membaca buku. Untuk siswa yang bertipe campuran ini diperlukan keterampilan bagi seorang guru untuk memilih media atau alat peraga yang sesuai dalam menyampaikan materi pelajaran. Untuk siswa yang sesuai dalam menyampaikan materi pelajaran. Untuk siswa yang bertipe kombinatif ini cara belajarnya adalah bisa mengeraskan kalau ia membaca dan mencoret-coret kata yang dianggap perlu karena alat indera yang berfungsi dalam belajarnya lebih dari satu.

Disamping keenam tipe belajar di atas, ada pula tipe belajar lainnya yaitu bertipe belajar kelompok dan bertipe belajar sendiri. Siswa tergolong bertipe belajar sendiri, apabila ia mengulangi kembali apa yang telah ia pelajari di sekolah setelah tiba di rumah atau di ruangan khusus yang jauh dari tempat-tempat keributan. Sedangkan siswa yang bertipe belajar kelompok akan lebih berhasil bila dibantu dengan suasana berkelompok dengan sejumlah teman-temannya. Dengan cara berkelompok, siswa juga dapat tolong-menolong seperti yang pandai menolong yang kurang pandai, yang kurang bersemangat dapat dibantu oleh temannya yang lain. 
Tipe belajar dapat dibagi juga ke dalam delapan macam tipe yang dipandang sebagai tahap-tahap yang saling mendasari mulai dari tahap yang di bawah. Namun, tidak dapat dipastikan, bahwa tipe I menjadi landasan bagi tipe II sampai dengan tipe VIII; karena itu urutan hirarkis baru dimulai pada tipe II ke atas. ${ }^{10}$ Urutan secara hirarkis adalah bahwa tipe-tipe belajar itu saling mendasari yakni tipe belajar yang dibawah menjadi landasan bagi tipe belajar tipe diatasnya. Artinya, siswa yang tidak mengenai tipe belajar keempat, misalnya akan mengalami kesulitan dalam tipe kelima sampai tipe kedelapan. Delapan tipe belajar yang dimaksud adalah :
a. Belajar sinyal (Conditioning ala Paviov)
b. Belajar perangsang-reaksi, dengan mendapat penguatan/peneguhan (Conditioning ala Skinner)
c. Belajar membentuk rangkaian gerak-gerak (Chaining Motorik)
d. Belajar asosiasi verbal (Chaining Verbal)
e. Belajar diskriminasi yang jamak (Multiple discrimination)
f. Belajar konsep (Concept learning)
g. Belajar kaidah (Rule learning)
h. Belajar memecahkan masalah (Problem solving). ${ }^{11}$

\section{a. Tipe belajar sinyal (signal)}

Nama tipe belajar tipe ini diberikan oleh penemunya yaitu Ivan Paplov. Belajar dalam hal ini adalah sesuatu menjadi tanda bagi hal yang lain untuk menimbulkan reaksi. Yang menjadi pokok dalam belajar adalah stimulus dan respon. Lama-kelamaan stimulus itu menimbulkan reaksi misalnya, anak kecil belajar untuk tidak memanjat pohon, bukan karena anak itu pernah jatuh dari pohon, akan tetapi setiap kali ia memanjat ibunya selalu memukulnya atau paling tidak ibunya berkata keras jangan padanya. Dengan sendirinya anak merasa takut apabila ia dekat-dekat dengan pohon sehingga lama-kelamaan terbentuklah hubungan antara memanjat pohon dan tindakan ibu. Dengan demikian, memanjat

\footnotetext{
${ }^{10}$ Winkel, Psikologi Pengajaran, Op Cit., h. 65

${ }^{11}$ Ibid., h. 66
} 
pohon tanda (signal) bagi anak tersebut akan menyusul hukuman ibu. Akhirnya, anak itu tidak akan pernah lagi memanjat pohon meskipun ibunya tidak ada didekatnya.

\section{b. Tipe belajar perangsang-reaksi dengan mendapat penguatan}

Tipe belajar ini diselidiki oleh Skinner dimana unsur pokok dalam tipe belajar ini adalah peneguhan dan penguatan. Yang dimaksud dengan penguatan atau peneguhan dalam tipe belajar ini adalah perbuatan atau reaksi yang salah tidak mendapat peneguhan. Misalnya seorang anak yang baru saja belajar bahasa asing diberi peneguhan setiap kali ia berbuat yang tepat atau menjawab dengan benar supaya lain kali ia melakukan sesuatu yang sama. Bentuk penguatan dapat berupa pemberian hadiah seperti buku tulis, pujian, dengan kata-kata atau izin untuk melakukan sesuatu yang disenangi anak.

\section{c. Tipe belajar membentuk rangkaian gerak-gerak (motorik)}

Dalam belajar semacam ini, terdapat sejumlah langkah atau gerakan sebagai mata rantai dalam keseluruhan rangkaian gerakan yang dilakukan secara berurutan. Dengan demikian, seorang anak atau siswa harus mampu melakukan suatu gerakan menyusul gerakan seperti main bola volley di sekolah, dalam mata pelajaran olahraga, beberapa gerakan harus dilakukannya, mulai dari cara memegang bola sampai dengan cara memukul dengan tepat.

\section{d. Tipe belajar asosiasi verbal atau belajar menghubungkan}

Suatu kata dengan suatu objek yang berupa benda, orang atau kejadian dan merangkaikan sejumlah kata dalam urutan yang tepat. Misalnya, kalau kita perlihatkan ayat-ayat kepada anak memberikan nama (cap verbal) pada objek itu adalah Al-Qur'an. Belajar asosiasi verbal yang lain misalnya anak belajar merangkaikan kata-kata dalam sejumlah kalimat seperti menghafal lagu qasidah. Demikian pula dengan membentuk rangkaian kata menggunakan cara menghafal yang mudah seperti dalam singkatan, misalnya: MUI adalah singkatan dari Majelis Ulama Indonesia, pangkopkamtib adalah singkatan dari Panglima Komando Operasi Keamanan dan Ketertiban dan lain sebagainya. 


\section{e. Tipe belajar diskriminasi yang jamak atau belajar berdasarkan diskriminasi}

Dalam belajar seperti ini, adalah tipe belajar berdasarkan diskriminasi. Belajar berdasarkan diskriminasi banyak terdapat dalam kehidupan sehari-hari. Kita dapat membedakan bentuk, warna, lokasi, luas, nada, huruf, nama-nama, wajah orang, peristiwa, rasa minuman dan makanan, suhu, dan sebagainya. ${ }^{12}$

Cara belajar diskriminasi ini sangat berfungsi kalau siswa belajar mengaji atau dalam mata pelajaran Qur'an dan Hadits yaitu siswa harus membedakan huruf-huruf hijaiyah dengan tepat agar tidak menimbulkan salah arti, misalnya bunyi "kaf"” berbeda dengan bunyi " $Q a f$ ", dan lain sebagainya.

\section{f. Tipe belajar konsep (concept learning)}

Konsep adalah satuan arti yang mewakili sejumlah obyek yang memiliki ciri-ciri yang sama. ${ }^{13}$ Dengan konsep, sesuatu kita ketahui mempunyai sifat yang terdapat dalam suatu benda yaitu apakah dinyatakan dengan nama, bentuk, ukuran, maupun warna. Konsep atau pengertian terdapat benda yang konkrit (nyata) dapat diperoleh lewat pengamatan sedangkan terhadap benda non konkrit (abstrak) dapat diketahui dengan definisi. Namun, kalau siswa tidak mempunyai pengertian tentang suatu benda sebelumnya, sulitlah bagi siswa tersebut untuk menggolong-golongkan benda itu mana yang termasuk kacang, padi, dan wortel.

Siswa-siswa Tsanawiah sudah memiliki sejumlah konsep sewaktu memasuki sekolah. Mereka telah mengenal konsep seperti meja, air, Al-Qur'an, sembahyang dan sebagainya. Akan tetapi masih banyak konsep yang harus dipelajari yang baru bagi mereka misalnya: konsep tauhid, sejarah, akhlak, dan sebagainya.

\section{g. Tipe belajar kaidah (rule learning)}

Pada tipe belajar di atas (tipe keenam) siswa telah mengetahui konsepkonsep suatu benda. Konsep tersebut dihubungkan atau dikombinasikan satu sama lain sehingga lahirlah sesuatu yang disebut kaidah. Misalnya: ketika siswa belajar matematika yakni konsep tiga kali konsep empat sama dengan 12 (3 x $4=12)$.

${ }^{12}$ S. Nasution, Berbagi Pendekatan dalam Proses Belajar Mengajar (Jakarta: Bumi Aksara, 1992), h. 159

${ }^{13}$ Winkel, Op.Cit., h. 57 
Belajar kaidah ini sangat banyak di jumpai dalam mata pelajaran di tingkat Tsanawiah dan Aliyah seperti mata pelajaran Bahasa Arab (Nahu), Bahasa Inggris (Grammar) atau kaidah Ushul Fiqih.

\section{h. Tipe belajar memecahkan masalah (problem)}

Mempelajari kaidah seperti pada tipe tujuh di atas memegang peranan penting terutama dalam tipe belajar ini, yakni memecahkan masalah. Masalah yang dihadapi dapat dipecahkan dengan cara menghubungkan-hubungkan beberapa kaida sedemikian rupa sehingga terbentuklah suatu pelajaran baru karena dengan memecahkan masalah siswa harus berpikir dengan menggunakan kaidah-kaidah yang sudah di ketahui sebelumnya. Dalam hal ini, penguasaan aturan-aturan seperti prasyarat untuk memecahkan masalah. ${ }^{14}$

Langkah-langkah dalam memecahkan masalah sebagai berikut :

a. Menyadari adanya masalah;

b. Melihat hakekat masalah dengan jelas;

c. Berpegang teguh pada pokok-pokok masalah, selama kita menyelidikinya;

d. Mengajukan hipotesis;

e. Mengumpulkan data atau informasi;

f. Analisis dan sintesis data;

g. Mengambil keputusan / kesimpulan;

h. Mencoba dan melaksanakan kesimpulan, dan

i. Menilai kembali keseluruhan pemecahan masalah. ${ }^{15}$

Dengan memperhatikan hal-hal di atas, maka pendidik mampu melakukan proses pembelajaran dengan baik dan hasilnya sesuai apa yang sudah dicantumkan dalam rencana pembelajaran.

\section{B. Kesimpulan}

Tipe belajar yang dimiliki siswa berbeda-beda, ada yang bertipe visual, auditif dan kombinatif, tipe-tipe belajar yang paling banyak dimiliki siswa adalah tipe

\footnotetext{
${ }^{14}$ Ibid, h.

${ }^{15}$ H. Sahabudin, Mengajar dan Belajar (Ujung Pandang: IKIP, 1994), h. 135-136
} 
kombinatif (campuran). Pendidik harus mampu memahami tipe-tipe belajar siswa secara mendalam, sehingga proses pembelajaran berjalan dengan baik dan hasilnya sesuai dengan apa yang diharapkan. pendidik akan di anggap memiliki kualifikasi kemampuan mengetahui tipe-tipe belajar dalam proses pembelajaran, apabila guru mampu menjawab mengapa, apa, dan bagaimana tipe-tipe pembelajaran itu, memahaminya sehingga dalam melakukan kegiatan proses pembelajaran tidak menemui hambatan.

\section{Daftar Pustaka}

Aminuddin Rasyad. Materi Pokok Media Pengajaran., Cet II; (Jakarta: Dirjen Pembinaan Kelembagaan Agama Islam dan Universitas Terbuka, 1993)

Abdurrahan, H. Pengelolaan pengajaran (Ujung Pandang: Bintang Selatan, 1994)

Arifin, Zainal. Evaluasi instruksional, Prinsip-prinsip tehnik Prosedur, Cet I; (Jakarta: CV Rajawali Karya, 1998)

Abimanyu, Soli. Dianostik Kesulitan Belajar (Ujung Pandang: FP. IKIP, 1980)

Ali, Mahmud. Guru dalam proses belajar mengajar (Bandung: Sinar Baru Algesindo, 1996)

Ahmadi, Abu dkk. Psikologi Belajar, Cet V; (Jakarta: Rineka Cipta, 1991)

AM. Sardiman. Interaksi dan Motivasi Belajar, Cet V; (Jakarta: PT Raja Grafindo Persada, 1994)

Arikunto, Suharsini. Prosedur Penelitian (Jakarta: Rineka Cipta, 1998)

Bahar, Ahmad dkk. Penuntun Praktis Cara Belajar dan Mengajar yang Efisien, (Surabaya: CV. Karya Utama)

Departemen Pendidikan dan Kebudayaan RI., Kamus Besar Bahasa Indonesia (Jakarta: Balai Pustaka, 1988) 
Hermawan Warsito. Pengantar Metodologi Penelitian, (Jakarta: PT Gramedia Utama, 1992)

H. Sahabudin. Mengajar dan Belajar (Ujung Pandang: IKIP, 1994)

Kartini Kartono, dkk. Kamus Psikologi (Bandung: Pioneer Jaya, t.th)

Sudarsono. Kamus Filsafat dan Psikologi (Jakarta: Rineka Cipta, 1993)

Slameto, dkk. Belajar dan Faktor-faktor yang Mempengaruhinya (Jakarta: PT Rineka Cipta, 1995)

Sriyono, dkk. Tekhnik Belajar Mengajar dalam CBSA, Cet I; (Jakarta: Rineka Cipta, 1992)

S. Nasution, Berbagai Pendekatan dalam Proses Belajar Mengajar (Jakarta: Bumi Aksara, 1992)

Suharsimi Arikunto, Prosedur Penelitian Suatu Analisis Praktek, Cet VII; (Jakarta: PT Rineka Cipta, 1995)

Sutrisno Hadi. Metodologi Research Jilid I, Cet XII; (Yogyakarta: Andi Offset, 1990)

W.J.S. Poerdarminto. Kamus Umum Bahasa Indonesia Cet V; (Jakarta: Departemen Pendidikan dan Kebudayaan, PN. Balai Pustaka, 1968)

W.J.S. Winkel. Psikologi Pengajaran (Jakarta: PT Gramedia, 1989) 